\title{
The Use of Diacrylic Resins in Dental Restorations
}

\author{
CRISTIAN ROMANEC ${ }^{1}$, CRISTINEL IONEL STAN²*, MARIUS VALERIU HINGANU2*, MONICA MIHAELA SCUTARIU3*, \\ SORANA ROSU ${ }^{4}$, DELIA HINGANU2 \\ ${ }^{1}$ Grigore T.Popa University of Medicine and Farmacy lasi, Department of Orthodontics, 16 Universitatii Str., 700115, Iasi, Romania \\ ${ }^{2}$ Grigore T.Popa University of Medicine and Farmacy lasi, Department of Morphofunctional Sciences I, Discipline of Anatomy, \\ 16 Universitatii Str., 700115, Iasi, Romania \\ ${ }^{3}$ Grigore T. Popa University of Medicine and Pharmacy lasi, Dental Medical Faculty, Department Implantology, Removable \\ Restorations, Technology, Oro-Dental-Diagnosis and Gerontostomatology, 16 Universitatii Str., 700115, Iasi, Romania \\ ${ }^{4}$ Grigore T.Popa University of Medicine and Farmacy lasi, Dental Medical Faculty, Discipline of community stomatology, \\ 16 Universitatii Str., 700115, Iasi, Romania
}

\begin{abstract}
The materials as well as the procedures used successfully in modern dental restorations are based on scientific selection criteria, which can predict outstanding results, both in terms of physiological aspects and the durability of the performed maneuvers. The rationale of using certain materials, as the success or failure in using certain techniques, has contributed to the evolution of dental restorations. The optimal way to combine the material with its applicability and finishing technique implies an exhaustive approach to the subject that still requires research, that adress to specialists, in order to improve its refinement and development.Among the restoration materials, those that satisfy the aesthetic requirements of the patients are considered to be composite resins. With all the advantages resulted from their intrinsic characteristics, it should be noted that composite resins still have inconveniences, primarily linked to the polymerization shrinkage, which causes a gap between the obturation and the dental tissue, resulting in the formationof marginal microinfiltrations with all the drawbacks associated with it. The purpose of the experimental research is to evaluate the marginal microinfiltrations at the level of the class II cavities restoration with composite diacrylic resins, according to various techniques of restoration and to establish the optimal technique to minimize side effects.
\end{abstract}

Keywords: diacrylic resins, techniques of restoration, obturation.

The last step in the treatment of simple caries is the restoration of coronary morphology with a a microprosthesistechnically named obturation [1-3]. Stopping the development of the caries process is performed by excision of all altered tissue, resulting in a solution of continuity in the dental tissues. Dental composites and their adhesive systems allow maximal preservation of dental rigid structures by providing both resistance, and minimal pulp inflammation during restoration.

Before this is done, the patient will be questioned abouthis medical history: the presence of general chronic diseases such as diabetes mellitus, former surgical interventions, drug allergies. These co-morbidities can influence clotting factors and tissue scarring rates [4- 7].

For the proper rendering of the anatomical shape of the teeth in the prosthesis process, it is necessary to know the anatomic particularities of each tooth, particularly for the dental crown.As anatomical features, incisors and canines have 1 root and 1 channel; the upper first premolar has 2 roots and 2 channels; second superior premolar and lower premolars have 1 rootand 1 channel; upper molars have 3 roots and 3 channels; lower molars have 2 roots and 3 channels. Wisdom tooth have an inconsistent root morphology. Of the multitude of anatomical variations in each tooth, the ones listed above are the most common.

Teeth are distinguished by several criteria, whose knowledge is of particular importance in prosthetics, inmodeling anatomic shapeand in making the physiological aspect of prostheses. The most important criteria would be: a root criterion, determined by the direction of the root axis deviation that indicates the origin in dental hemiarcade, the angles of the crowns of anterior teeth, the curvature of the vestibular surface, the crown edge, the number of cusps, the size and position on the occlusal surface at the lateral teeth.

Dyacrilic resins are materials with a good quality/ price ratio and a remarkable physiognomic aesthetics [8].Face aging phenomena affect the nasal cavity, the lacrimal apparatus and the oral cavity. Thus, a very important role in prosthetics is the maintenance of the aesthetic aspect and the local impact it produces - the modification of the oral cavity anatomy, the influence of the salivary secretion, the challenge of the neuralgia [9-13].

The diacrylic composite resins (DCR) used by practitioners in many clinical situations in dental restorations lead to successful results,but only through learning proper techniques and respecting the technologyof restoration [14- 17].

Of utmost importance are the quality of the polymerization process and the shrinkage of the outlet, two issues that are currently unresolved in the treatment of odontal lesions with DCR [18-23]. The objective of the research is to evaluate the marginal microinfiltrations in composite resin restorations, depending on different restorative techniques at the level of the class II cavities. It will be highlighted the optimal method of restoration and the techniques that can be learned and applied by practitioners in order to optimize the clinical behavior of the photo polymerizable diacrylic composite resins, used in direct restorations.

\section{Experimental part \\ Materials and methods}

In order to achieve experimental research,it have been used a number of specific dental materials and

\footnotetext{
*email : cristi_stan00@yahoo.com, hanganu.marius@yahoo.com,monascutaru@yahoo.com
} 
investigations were conducted with specialized equipment.

Materials: maxillary and mandibulary molars and premolars; diestonegypsum; diamond drill (spherical, cylindrical, inverted cone) for finishing; diamond disk; applicators; interdental wedges; metal matrices; portmatrice; $36 \%$ phosphoric acid; Adhesive; fluid composite (3M ESPE); composite; methylene blue.

Equipment for the investigation of restorations: optical endodontic microscope (Zumax / figurel) and digital camera (Nikon D3100).

The study was conducted on 30 maxillary and mandibulary molars and premolars, collected over a period of 3 months from dentists with private practice.

After extraction, the teeth were sanitized and kept in physiological saline. They were then inserted into gypsum blocks with the root portion, and the contact point between them was made in order to highlight their situation in the oral cavity. On those 30 maxillary and mandibulary molars and premolars, were prepared class II cavities by using spherical, cylindrical and inverted cone diamond drills. The teeth were divided into 3 groups:

I. 10 teeth obturated using technique with prephotopolimerised composite inserted;

I1.10 teeth obturated using flow technique with liquid composite;

III.10 teeth obturated using stratification techniqueor oblique incremental technique (OIT), using viscous composite.

There after, the teeth were restorated using different techniques on the three groups of teeth.

Regardless of the filling technique, for all three groups of teeth, the following procedure was performed: the $36 \%$ orthohosphoric acid was used as etching solutionfor dental cavity for $20 \mathrm{~s}$; the cavity was washed for $15 \mathrm{~s}$; the cavity was dried by air jet from the dental unit; the adhesive was applied and photopolymerized for $20 \mathrm{~s}$.

For the first group of teeth, a first layer of compositefluid was applied to the gingival wall, a pre-photopolymerized insert was introduced, and then the cavity was closed, using through the stratification technique (fig. 1). For group II, a layer of 1 $\mathrm{mm}$ of fluid composite was applied directly to the gingival wall of the cavity, and then the cavity was obturated through the stratification technique (fig. 1). For group III, the first composite layer was applied directly to the gingival wall, in oblique position and photopolymerized for $40 \mathrm{~s}$; the other layers were introduced by the same technique, the oblique incremental technique (OIT). After filling the cavities, the teeth were introduced into $1 \%$ methylene blue for $24 \mathrm{~h}$, after which they were cut using a diamond disk mounted to a straight piece in the vestibule-oral direction in $1 \mathrm{~mm}$ sections (fig. 2).

The sections were analyzed at the Zumax endodontic optical microscope, at 50X magnification. The images were taken with the Nikon D 3100 digital camera attached to the endodontic optical microscope (figs. 3- 5).

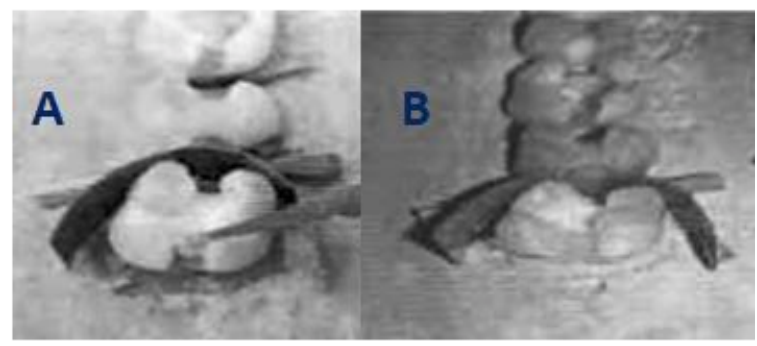

Fig. $1 A=$ Application of the adhesive; $B=$ Applying the fluid composite and the metal matrix (group I)

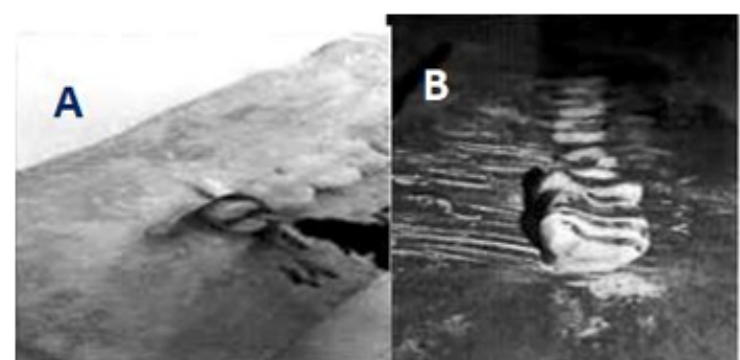

Fig. $2 A=$ Applying the fluid composite; $B=$ Vestibulo-oral sections (Group II )

The extent of infiltration was analyzed at the level of each section (mesial, central, distal) in the gingival, vestibular and

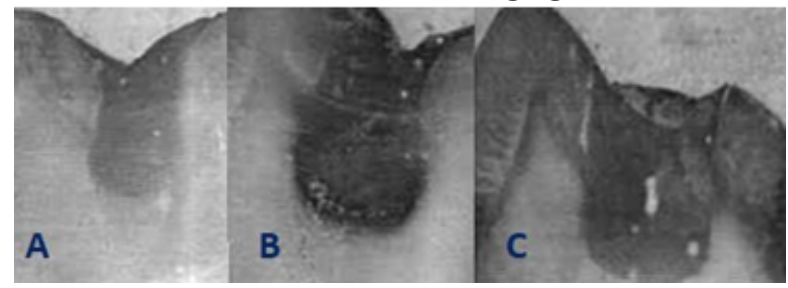

Fig. $3 A=$ Medial section; $B=$ Central section; $C=$ Distal section (group I)

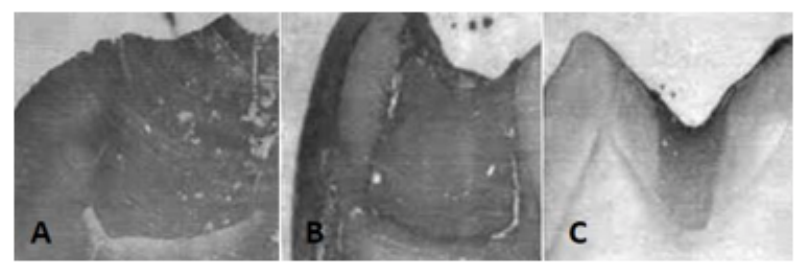

Fig. $4 A=$ Medial section; $B=$ Central section; $C=$ Distal section in second group

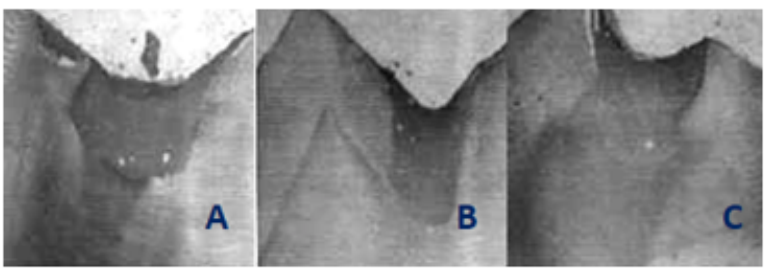

Fig. $5 A=$ Medial section; $B=$ Central section; $C=$ Distal section

oral walls, and the data obtained were processed by using Microsoft Excel program.

\section{Results and discussions}

After the research was done, the quality of restorations was evaluated.

It were compared the infiltrates from vestibular (V), oral (O) and gingival (G) walls, by analyzing those three sections (medial, central, distal) of the obturated teeth by those three restoration techniques. We then conducted a comparative study about the quality of restorations through the three experimental techniques used, by comparing the degree of infiltration of the oral, vestibular and gingival walls.

As seen in the technique with pre-photopolymerized inserts, the highest level of infiltration (83.33\%) occurs in the vestibular wall, followed by the oral wall (66.67\%) and then the gingival $(56,67 \%)$ one.

In the flow technique, the highest degree of infiltration occurs in the oral wall (86.67\%), followed by the vestibular wall (70\%) and then the gingival (30\%) wall.

In the IOT technique, the maximum infiltration rate is recorded in the vestibular wall (66.67\%), followed by the oral wall (63.33\%), the lowest infiltration rate is estimated in the gingival wall (50\%).

We observe that for the vestibular wall the highest degree of infiltration is encountered in the technique with pre- 
photopolymerized insert( $83.33 \%$ ), followed by flow technique (70\%) and IOT technique (67\%).

For the gingival wall, the highest infiltration rate is also recorded for the pre-photopolymerized technique (56.67\%), followed by the IOT technique (50\%) and the flow technique (30\%).

For the oral wall it can be observed that the highest degree of infiltration is recorded with the flow technique (87.67\%), followed by the technique with inserts $(66.67 \%)$ and the last place is the IOT technique (63.33\%).

Recent studies shows that a thin layer of fluid composite (0.5-1mm) has a superior marginal quality; the use of fluid composite liners can reduce the value of microinfiltrations in composite restorations, which is explained by the high percentage of the organic matrix of the fluid composite which increases the stress of shrinkage $[19,20]$.

A particular situation is that of minor patients, where prosthesis is recommended to be done after the written consent of the parents and after a prior clinical examination to exclude congenital malformations of the oral cavity [2431].

\section{Conclusions}

Marginal microinfiltrations are presented in a lower orhigher percentage in all 3 used techniques.Since the composite diacrylic resins undergo dimensional variations during the polymerization process, it is very important to use the proper technique in order to obtain a good adaptation of the material to the cavity and a corresponding marginal seal. The fluid composit applied to the gingival wall cause a better marginal closure (superior sealing and low infiltration) compared to other techniques, plus the advantage of partially absorbing the mechanical shocks resulting from the chewing process. The results of the study demonstrate that the stratification technique still remains a viable technique, the oblique layers having the advantage of low thickness and reduced contraction volume.

\section{References}

1.LLIESCU, A.,GAFAR, M., Cariologie si odontolerapie restauratoare. Ed. Medicala Bucuresti, 2011; 32-43, 139-143, 169-184,247-266, 374-388.

2.GRAHAM, J., MOUM, W.R.HUME, Conservarea si restaurarea structurii dentare. Ed. ALL Educapional, Bucureoti. 2006; 55-68, $121-154$.

3.FEATHERSTONE J-D.-The science and practice ofcaries prevention. Ini AmDent Assoc; 2000; 131:887-899 4.DANCIU M., LUNGULEAC T., GRIGORESCU C. Rom J Morphol Embryol., 56, no. 2, 2015, p. 545.

5.SALAHORU, P., GHICIUC, C.M., GRIGORESCU, C., HINGANU, M.V., LUPUSORU, C.E., The influence of thymectomy over Acetylcoline antibody anti-receptor concentration and over the clinical manifestations on myasthenia gravis patients. Rev.Chim (Bucharest), 69, no. 7,2018, p.2251-2253

6.HINGANU, D., HINGANU, M.V., BULIMAR, V., ANDRONIC, D., Rev. Chim. (Bucharest), 69, no 2, 2018, p. 371.

7.LUPASCU F.G., AVRAM I., AVRAM L., CONSTANTIN S.M., STAN C.I., LUPUSORU E.C., SAVA A., PROFIRE L. FARMACIA, 65, no. 4, 2017, p. 508.

8.ANDREIA A. CAVALHO et al. Marginal microleakageof classll composite resin restorations due to restorative tehniques. Revista odonto. cionc. 2010:25-2:165-169. 9.HINGANU M.V., COZMA R.S., CIOCHINA P., SCUTARIU I.A., ASIMIONOAIEI-SIMIONESCU C., HINGANU D. Rom J Morphol Embryol, 58, no 4, 2017, p. 1365.

10.HINGANU D., STAN C.I., TARANU T., HINGANU M.V. Rom J Morpholembryol., 58, no.4, 2017, p. 1327.
11.HINGANU D., SCUTARIU M.M., HINGANU M.V. The existence of labial SMAS-Anatomical, imaging and histological study. ANNALS OF ANATOMYANATOMISCHER ANZEIGER, 2018, 218: 271-275. https:/ /doi.org/10.1016/j.aanat.2018.04.009

12.COZMA S., DIMA-COZMA L.C., GHICIUC C.M., PASQUALI V., SAPONARO A., PATACCHIOLI F.R. BRAZILIAN JOURNAL OF MEDICAL AND BIOLOGICAL RESEARCH, 50, no.2, 2017, Article Number: e5577, DOI: 10.1590/1414-431X20165577

13.FRANCU L.L., HINGANU D., HINGANU M.V. Rom J MorpholEmbryol, 54, no.3(suppl), 2013, p.757.

14.CRAIG R.G., POWERS J.M., WALAHA I.C: Dentalmaterials-Properties and Manipulation, Mosby,2004 15.V.AGGARWAL el al. Effect of cyclic loading ommarginal adaptation and bond strength in direci vsindirect class II MO composite restorations.Operative Dentistry, 2008; 587-592

16.SIMONE DELIPERI. DAVID N. BARDWELL.An alternative method to reduce polymerization shrinkage in direct posterior composite restorations. JADA.2002; 133: 1387-1396

17.GARBEROGLIO R., COLI P., BRANNESIROM $M$. Contraction gaps in class II restorations with seffcured and light-cured resin composites. Am J. Dent, 1995; v. 8

18.ROMANEC, C., DRAGOMIR, B., BICA, C.. Rev.Chim. (Bucharest), 69, no.3, 2018, p.693-696.

19.MESAROS, A.S., ROMANEC, C.,MESAROS ,M., MOLDOVAN, M., BALDEA, I. Mat. Plast., 54, no. 4, 2017, p. 620-625.

20.ROMANEC C., DOROBAT V., ZETU I.N. REVISTA ROMANA DE BIOETICA, 11, no. 3, 2013, p. 66.

21.PFEIFER CS. FERRAEANE JL, SAKAGUCHI RL, BRAGA RR. Factors affecting photopolymerization stress in dental composites. J Dent Res. 2008,87(11): 10431047

22.KREVERLAAN GJ., FEILZER AJ. Polymerization shrinkage au contraction stress of dental resin composites. Dent, Mater., 2005; 21: 1151-11

23.ANDRE FIGUEIRIDO REIS et al. The effect of filling tehniques and a low viscosity composite liner on bond strength to class cavities. Jourmal of dentistry, 2003;31:59-66

24.DONLY K.J., WILD T.W. et al. An in vitro invesligations of the effect of glass inserts on the effective composite resin polymerization shrinkage. J. Dent. Res., 1989; 68-8: 1234-1237

25. ROMANEC, C., PACURAR, M. , DECUSARA, M., SCUTARIU,M.M.,HINGANU,D.,HINGANU,M.V., CIUPILAN, C., Rev. Chim.(Bucharest), 69, no. 4, 2018, p. 1002.

26. RUSU M.C., POALELUNGI C.V., VRAPCIU A.D., PADURARU L., DIDILESCU A.C., STAN C.I., ANATOMICAL RECORD-ADVANCES IN INTEGRATIVE ANATOMY AND EVOLUTIONARY BIOLOGY, 297, no. 2, 2014, p.301

27.MATEI, M.N., EARAR, K., TRINCA, L.C., Degradation characteristics of poly-tetrafluorethylene coatings on stainless steel orthodontic wires immersed in tuna fish derived products, Rev.Chim.(Bucharest), 67, no.4, 2016, p.800-807

28.MARECI, D., EARAR, K., ZETU, I., ET AL., Comparative electrochemical behaviour of uncoated and coated Ni-Ti for dental orthodontic wires, Mat.Plast., 52, no.2,2015, p.150-153

29. ANTOHE, M.E., AGOP FORNA, D., DASCALU, C.G., Implications of digital image processing in the paraclinical assessment of the partially edentated patient, Rev.Chim.(Bucharest), 69, no.2, 2018 p.521524

30. POPESCU, E., AGOP FORNA, D., EARAR, K., FORNA, N.C., Bone substitutes used in guided bone regeneration technique review, Mat. Plast., 54, no.2, 2017, p. 390-392

31.CHECHERITA, L., BELDIMAN, M.A., STAMATIN ,O., et al. Aspects on structure of materials used for different types of occlusal splints. 64(8), 2013,p.864-867

Manuscript received: 12.04 .2018 